\title{
THE EFFECT OF HEATING IN FOOD PROCESSING ON THE NUTRITIONAL VALUE OF SOME COMMON FOOD FATS
}

\author{
ERKKI Uksila and RAKel Kurkela \\ Department of Nutritional Chemistry, University of Helsinki, \\ Helsinki, Finland
}

Received August 8, 1966

The possible part played by saturated fats in the etiology of cardiovascular diseases has in Finland undoubtedly increased the consumption of vegetable oils at the expense of butter and other animal fats, which are the principal food fats in this country. It is conceivable, therefore, that by now vegetable oils form a noteworthy part of the Finnish national diet.

Vegetable oils which are liquids at room temperature and can not be spread on bread instead of butter are chiefly used in food preparation and are often exposed to strong heat treatment. Especially in unsaturated oils heating may cause changes in the chemical structure and the sensory properties, e.g. flavour and colour. The main chemical alterations occurring in fats heated in the presence of air are oxidation and polymerization of partially oxidized fats. The physiological harmfullness of heated fats has been manifested in experimental animals as growth retardation (10), intestinal disorders $(1,2,3,4,6)$, and as symptoms of avitaminosisA and -E (1,9). Carcinogenic activity of heated fats is reported by some research workers $(8,11)$. KRITCHEVSKY $(7)$ found that atherosclerosis in rabbits can be intensified by heating the corn oil of their diet.

The reactivity of vegetable oils raises the question of whether they are suited to all kinds of uses in the preparation of foods. The purpose of the following investigation is to compare the heat resistance of some common food fats. Because of its high linoleic acid content safflor oil was selected to represent a highly unsaturated vegetable oil. Butter and lard, which contain oleic acid as the main unsaturated component, are examples of typical saturated food fats of animal origin.

\section{Material and methods}

Female and male Sprague-Dawley rats weighing from 84 to $151 \mathrm{~g}$ were fed with diets containing 60 cal.- $\%$ fat to be tested. The basal diet was composed of wholemeal flour $580 \mathrm{~g}$, dried brewer's yeast $100 \mathrm{~g}$, casein $150 \mathrm{~g}$, and salt mixture $20 \mathrm{~g}$ 


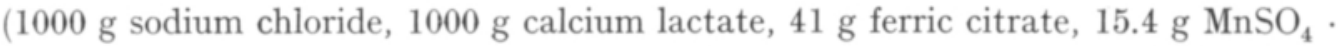
$4 \mathrm{H}_{2} \mathrm{O}, 2.4 \mathrm{~g} \mathrm{CuSO}_{4} \cdot \mathrm{H}_{2} \mathrm{O}, 0.2 \mathrm{~g}$ potassium iodide). To this ratio, $3 \mathrm{~g}$ of fat soluble vitamin mixture ( $1 \mathrm{~g}$ of $\alpha$-tokoferol, and $10 \mathrm{mg} \mathrm{K}$-vitamin in $50 \mathrm{~g}$ cod liver oil) in $455 \mathrm{~g}$ of the test fat were added. The diets were stored at about $+4^{\circ} \mathrm{C}$ under carbon dioxide.

The fats to be tested were commercial butter (Valio), lard (Elanto), and safflor oil (Kasviöljy Oy). Before use the butter was melted and filtered in order to separate the proteins, salts and water. The lard and safflor oil were used as such. The heating of fats was carried out in portions of $500 \mathrm{~g}$ at $200^{\circ} \mathrm{C}$ for 20 hours.

The fatty acid analyses were performed using a temperature programmed Perkin-Elmer gas chromatograph Mod. 800, with a flame ionization detector. The fatty acid methyl esters were separated in stainless steel columns packed with $8 \%$ BDS on Chromosorb or $15 \%$ EGS on Celite 545, 80-100 mesh. The quantitation of the fatty acid was made using a discintegrator. The peaks were identified by using authentic reference substances and RT-values known in the literature.

Food and water was allowed to all animals ad libitum. The weight gain and the food consumption were registered daily. The faeces were collected during the whole experimental period. Samples of $0.5 \mathrm{~g}$ were acidified with hydrochloric acid and extracted with petroleum ether in order to determine the approximate absorption of fats and their fatty acid composition.

\section{Results and discussion}

The weight gain of rats is seen in Fig. 1. Although the experiment lasted 13 days only large differences in the weight gains occurred between the groups. All

Fig. 1. Weight gain of rats when fresh and heated butter, lard and safflor oil is allowed 60 cal.- $\%$ in the diet.

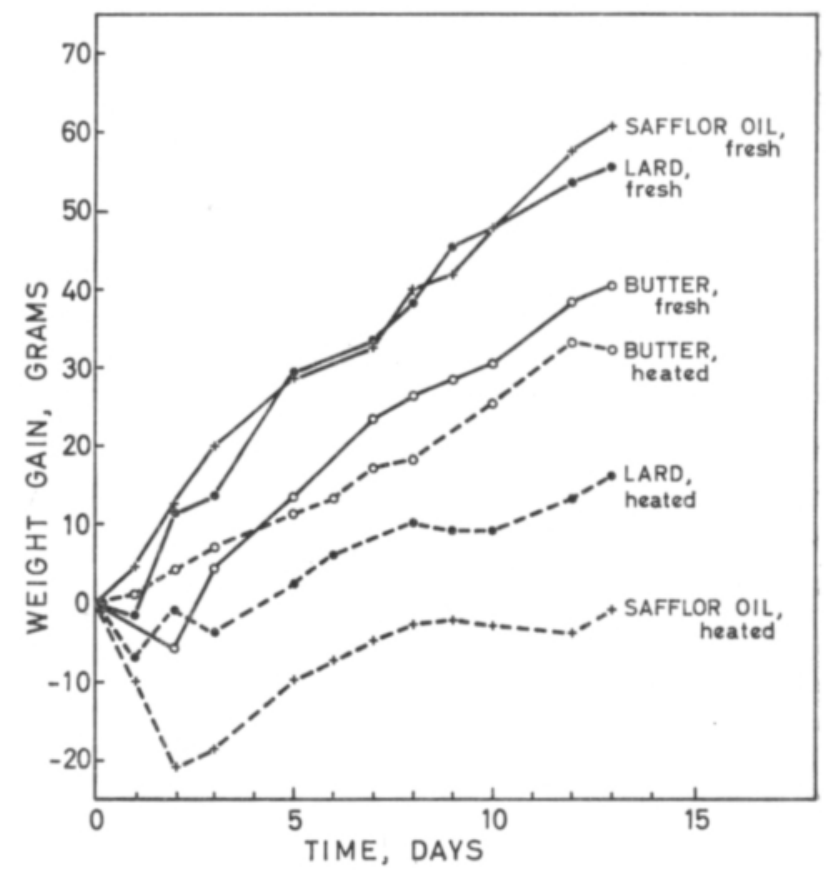


rats receiving fresh fat showed more active growth than those fed with the corresponding heated fat. In addition, the degree of the growth retardation was largely dependent on the type of the heated fat. Thus the difference between the butter groups was rather small. When calculating the relative growth rates: weight gain with fresh fat/weight gain with heated fat, it was only 1.3 for butter, but 3.5 for lard. The most drastic effect of the heating was seen, however, in the safflor oil group. During the first two days there was a rapid loss of weight when heated oil was given. Later the rats began to gain weight, although they did not fully reach the starting level before the end of the experiment.

One of the reasons for the growth retardation caused by heated fats seems to be the lowered food consumption (Table 1). The final weight order of the rats follows approximately the curve of the daily food consumption. There seems to be,

Table 1. Some data of the experiment with rats fed with fresh and heated fats at a level of 60 cal.- $\%$ in the diet

\begin{tabular}{|c|c|c|c|c|c|c|c|}
\hline \multirow{2}{*}{\multicolumn{2}{|c|}{ Group }} & \multirow{3}{*}{$\begin{array}{l}\text { Original weight of rats } \\
\qquad(\mathrm{g})\end{array}$} & \multirow{3}{*}{$\begin{array}{c}\begin{array}{c}\text { Food con- } \\
\text { sumption } \\
(\mathrm{g} / \mathrm{rat} / \text { day })\end{array} \\
9.9\end{array}$} & \multirow{3}{*}{$\begin{array}{c}\text { Growth } \\
\text { efficiency } \\
\text { of diet } \\
\text { (weight } \\
\text { gain } / 100 \mathrm{~g} \\
\text { diet) } \\
32\end{array}$} & \multirow{3}{*}{$\begin{array}{c}\begin{array}{c}\text { Fat in } \\
\text { faeces ( } \% \\
\text { of dry } \\
\text { weight) }\end{array} \\
33.2\end{array}$} & \multicolumn{2}{|c|}{$\begin{array}{c}\text { Absorption ( } \% \text { of the } \\
\text { fat ingested) }\end{array}$} \\
\hline & & & & & & $\begin{array}{l}\text { Appa- } \\
\left.\text { rent }^{1}\right)\end{array}$ & Real \\
\hline \multirow[t]{2}{*}{ Butter } & fresh & & & & & 93.6 & 95.1 \\
\hline & heated & 136 oิ; 134 ㅇ; 147 ㅇ & 9.8 & 25 & 29.2 & 92.5 & 94.7 \\
\hline \multirow[t]{2}{*}{ Lard } & fresh & 137 ô; 131 \&; 144 ㅇ & 11.4 & 38 & 21.0 & 96.1 & 97.9 \\
\hline & heated & 151 ô; 146 ㅇ; 133 q & 8.7 & 10 & 32.5 & 91.2 & 93.5 \\
\hline \multirow{2}{*}{ Sofflor oil } & fresh & 136 హิ; 134 \&; 145 우 & 10.6 & 44 & 20.9 & 95.2 & 97.2 \\
\hline & heated & 140 oิ; 132 ㅇ; 146 우 & 6.2 & 00 & 35.6 & 88.3 & 91.2 \\
\hline
\end{tabular}

however, some other additional factor. It appears that when the growth efficiency of the diets (weight gain/100 g diet) is calculated, heated fats do not promote growth as well as do equal amounts of fresh fats.

The apparent ${ }^{1}$ and real absorption percentages are presented in Table 1 . The tat content of the dry faeces on the basal diet was established at about $14 \%$. When the 60 cal.- $\%$ fat diet contained only 65 weight- $\%$ basal diet, about $9 \%$ of the diy weight of the faeces was considered as metabolic fat. In the butter groups there was no marked difference between the absorption of fresh and heated samples, both were absorbed equally well, i.e. about 95 per cent of the ingested fat. For heated lard and safflor oil these figures were 93 and 91 per cent, as compared to 98 and 97 for fresh lard and oil, respectively. This impairment of absorption could not, however, account for so pronounced a growth depression in the animals as was apparent.

The absorption values of fresh butter, lard and safflor oil $(95,98$ and 97$)$ are of

1) Metabolic fat was not taken into consideration 
Table 2. The fatty acid composition of the faeces fats as analysed by gas chromatography. Rats allowed 60 cal.- $\%$ fresh or heated butter, lard or safflor oil or basal diet only.

\begin{tabular}{|c|c|c|c|c|c|c|c|c|c|}
\hline \multirow{2}{*}{$\begin{array}{l}\text { Fatty acid } \\
\text { Common } \\
\text { name }\end{array}$} & \multirow[b]{2}{*}{$\begin{array}{c}\text { Short hand } \\
\text { design. }\end{array}$} & \multicolumn{2}{|c|}{ Butter } & \multicolumn{2}{|c|}{ Lard } & \multicolumn{2}{|c|}{ Safflor oil } & \multicolumn{2}{|c|}{ Basal diet } \\
\hline & & Fresh & Heated & Fresh & Heated & Fresh & Heated & Mean & Range \\
\hline & $4<\mathrm{n}<8$ & - & - & - & - & - & - & 7.7 & $2.1-14.7$ \\
\hline \multirow[t]{2}{*}{ Caprylic } & $8: 0$ & 0.9 & 2.4 & 0.7 & 4.9 & 2.0 & 7.4 & 0.8 & $0.1-2.0$ \\
\hline & $9: 0$ & - & - & - & - & - & - & 0.8 & $0.4-1.4$ \\
\hline \multirow[t]{2}{*}{ Capric } & $10: 0$ & 0.4 & 0.9 & 0.1 & 0.2 & 0.1 & - & 1.4 & $0.4-3.2$ \\
\hline & $10: 1(+11: 0)$ & - & - & - & - & - & - & 0.9 & $0.3-1.7$ \\
\hline \multirow[t]{4}{*}{ Lauric } & $12: 0$ & 1.1 & 1.8 & 0.2 & 0.4 & 0.4 & 0.3 & 1.5 & $0.8-2.4$ \\
\hline & $12: 1(+13)^{b}$ & - & - & - & - & - & - & 0.7 & $0.3-1.0$ \\
\hline & $13: 6$ & 0.2 & 0.3 & 0.1 & 0.1 & 0.1 & - & 0.9 & $0.4-1.5$ \\
\hline & $14^{b}$ & 0.6 & 0.6 & 0.3 & 0.2 & 0.4 & 0.3 & 1.5 & $1.1-2.0$ \\
\hline \multirow[t]{4}{*}{ Myristic } & $14: 0$ & 3.7 & 6.3 & 1.0 & 1.3 & 1.2 & 0.8 & 2.6 & $1.9-3.1$ \\
\hline & $15(+14: 1)^{b}$ & 3.8 & 3.9 & 2.0 & 1.3 & 3.2 & 2.3 & 6.5 & $4.8-10.1$ \\
\hline & $15: 0$ & 2.8 & 3.1 & 1.2 & 1.3 & 2.1 & 1.3 & 4.4 & $3.6-6.8$ \\
\hline & $16^{b}$ & 1.1 & 1.4 & 0.6 & 0.6 & 1.0 & 2.3 & 0.9 & $0.5-2.5$ \\
\hline \multirow[t]{3}{*}{ Palmitic } & $16: 0$ & 24.4 & 23.4 & 19.9 & 19.1 & 9.0 & 8.3 & 11.9 & $10.5-14.3$ \\
\hline & $16: 1$ & 3.2 & 2.1 & 1.6 & 1.3 & 3.0 & 3.9 & 5.8 & $5.1-6.5$ \\
\hline & $17: 0$ & 2.5 & 2.1 & 1.2 & 1.4 & 1.4 & 1.5 & 2.6 & $1.6-3.9$ \\
\hline Stearic & $18: 0$ & 15.8 & 13.9 & 49.5 & 47.8 & 14.2 & 15.9 & 4.9 & $3.4-7.0$ \\
\hline Oleic & $18: 1$ & 13.4 & 15.2 & 9.5 & 11.1 & 16.4 & 11.1 & 12.2 & $10.6-13.8$ \\
\hline Linoleic & $18: 2(+19)$ & 15.5 & 12.9 & 7.3 & 5.4 & 22.1 & 15.4 & 19.3 & $16.9-22.1$ \\
\hline Linolenic & $18: 3$ & 2.9 & 2.4 & 0.5 & 1.5 & 3.2 & 4.1 & 4.0 & $3.0-4.8$ \\
\hline \multirow[t]{3}{*}{ Arachidic } & $20: 0$ & 2.4 & 2.3 & 1.3 & 1.4 & 4.0 & 3.2 & 4.2 & $3.0-6.2$ \\
\hline & $\mathrm{n}>20$ & 4.3 & 2.1 & 1.9 & 1.4 & 4.0 & 5.3 & 3.6 & $2.0-4.9$ \\
\hline & Unidentiafied & 1.3 & 2.9 & 1.1 & - & - & 9.1 & - & - \\
\hline
\end{tabular}

the same order as the values presented in the literature. The mean figure of fat absorption is reported to be $95 \%$ or more (5) and that of butter and lard $98 \%(12)$.

The increased amount of unabsorbed fat is reflected in the fatty acid composition of the faeces fat, the fatty acid composition varying strongly according to the type of the diet fat (Table 2). The basal diet contained only $1.7 \%$ fat, mainly as wheat germ oil from wholemeal flour, the fatty acid composition of which is presented in Table 3 alongside that of the other diet fats. The amount of fat ingested on the basal diet has been so low that the unabsorbed part of it is negligible. The fatty acid composition of the faeces fat of rats fed with the basal diet thus represents the fatty acids of the metabolic fat. In the gas chromatography analysis $20-30$ components were distinquished in the metabolic fat (Fig. 2), twenty of these being identified. Table 2 presents the mean fatty acid composition of the metabolic fats from seven determinations during two weeks.

When comparing the fatty acid compositions of faeces fats derived from diet fats with that of metabolic fats (Table 2), differences can be seen not only between the butter, lard, and safflor oil groups, but also between the fresh and heated forms 


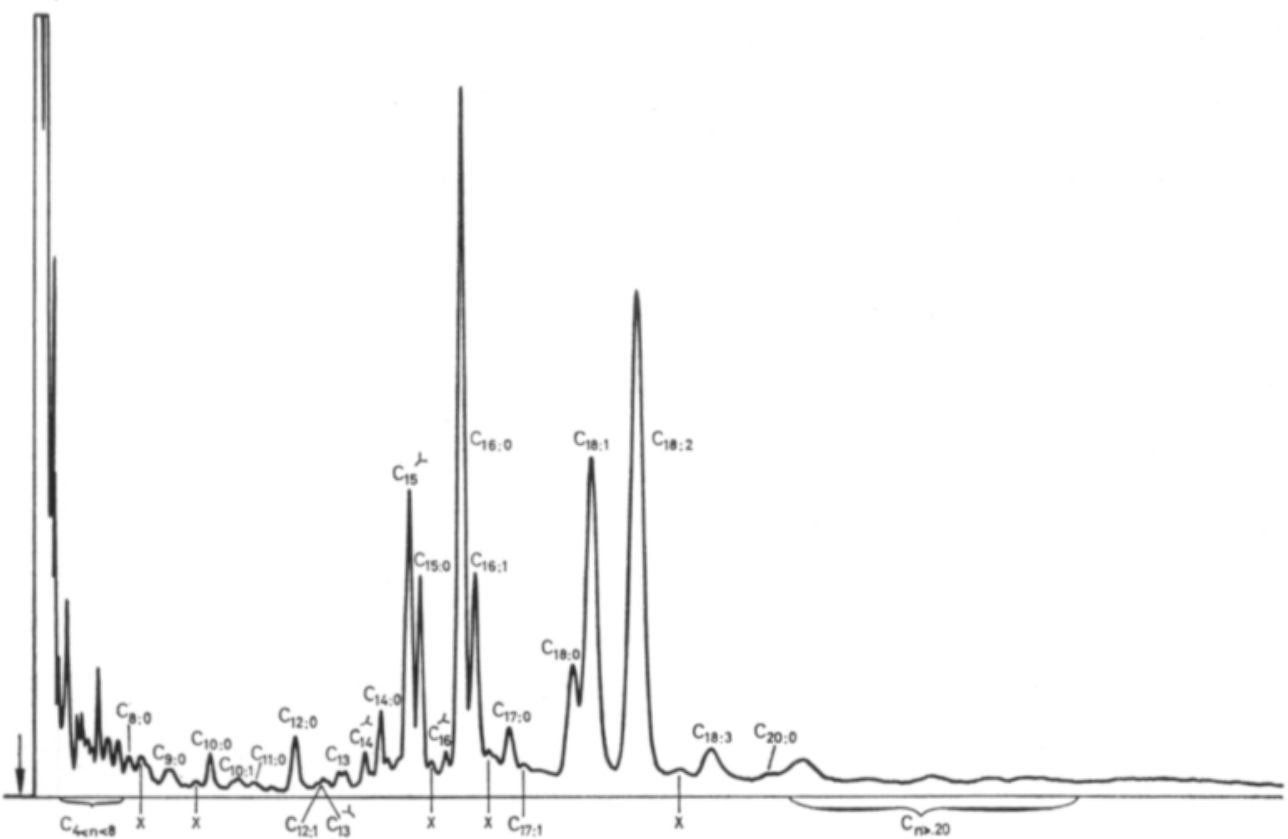

Fig. 2. Gas chromatogram of the fatty acid methyl esters of the faeces fats of rats on basal diet.

of the same fat. The mean percentage of linoleic acid in metabolic fat was $19.3 \%$. The unabsorbed part of fresh safflor oil, about $12 \%$ of the dry weight of the faeces, had a slight tendency to raise the linoleic acid content of the faeces $(22.1 \%$ linoleic acid). Heated safflor oil, on the other hand, had a tendency to lower the linoleic acid content of the faeces (15.4\% linoleic acid) despite the linoleic acid content of the ingested heated oil being as high as $61.6 \%$ and despite the great proportion of it $(35-9=26 \%)$ in the faeces. It appears, therefore, that the unabsorbed fraction of heated oil may produce a higher linoleic acid content in the faeces fat than would the metabolic fat. The low linoleic acid percentage probably thus refers to the selective absorption of linoleic acid from heated oil. The same tendency could be seen also when heated lard and butter were given to the rats, although the effects of heating did not become as clearly evident because of the low linoleic acid contents in these fats. On the contrary, the stearic acid content (in $\%: s$ ) of all the feed fats was higher than that of metabolic fat or even that of diet fat, e.g. the percentage of stearic acid was about 50 in the faeces of both lard groups. It seems evident that the absorption per cent of stearic acid is lower than that of whole fat.

The share of lower fatty acids $\left(\mathrm{C}_{4}-\mathrm{C}_{6}\right)$ in the faeces seemed to vary greatly even when the rats were fed upon basal diet only. This is partly due to the easy evaporation of these acids and their methyl esters during the analysis. Another explanation lies in their partly microbial origin. A common noticeable feature was a relatively high amount of caprylic acid in the faeces fats when heated fats were included in the diet. Since the caprylic acid contents of the heated fats was not higher than that of the fresh fats, the reason of its high content in the faeces fat is 
Table 3. The fatty acid composition of fresh and heated butter, lard and safflor oil and basal diet as analysed by gas chromatography.

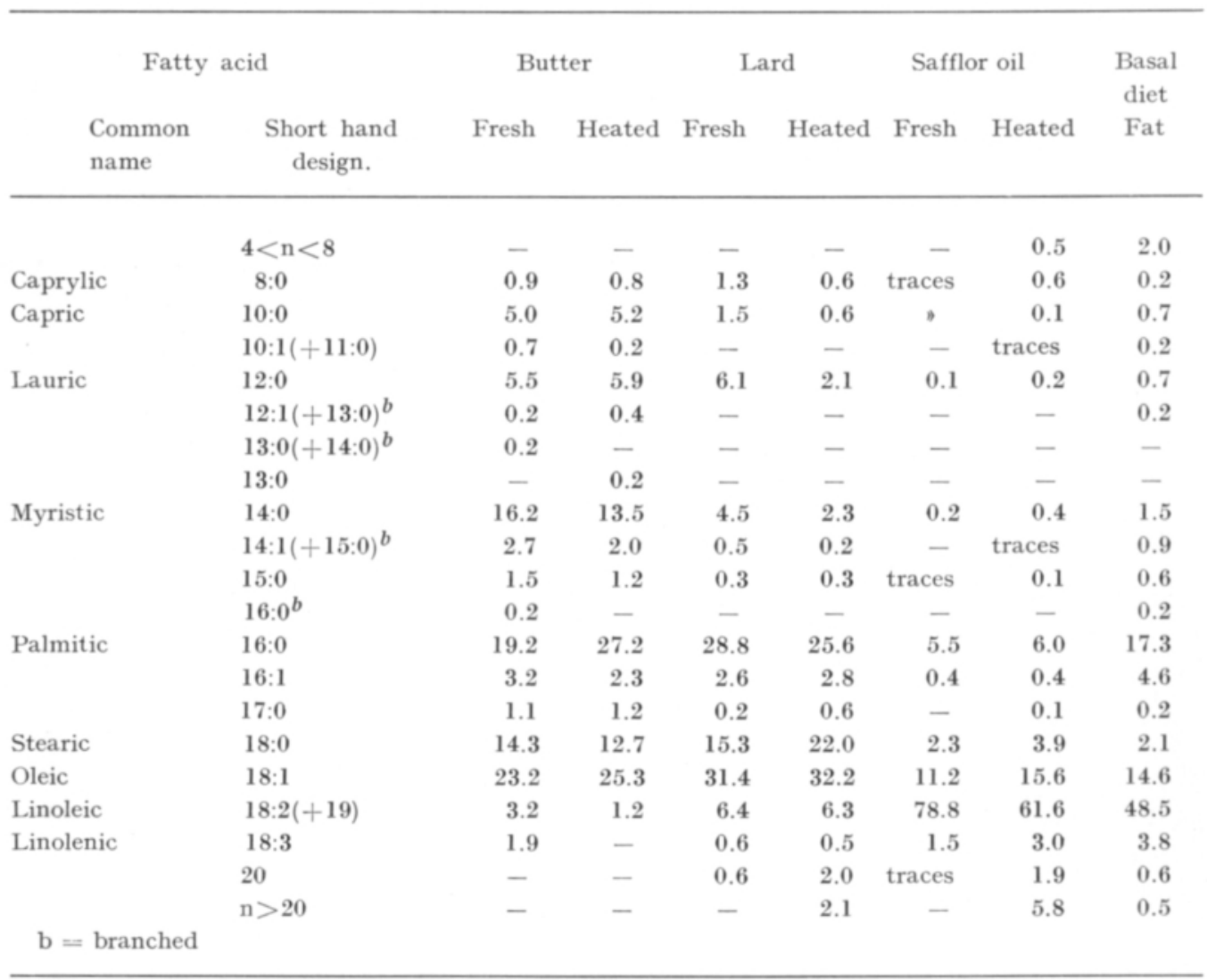

probably to be found in the activated degradation of the unabsorbed fraction by the intestinal flora.

\section{$S u m m$ ary}

The effect of strong heating $\left(20\right.$ hours at $\left.200^{\circ} \mathrm{C}\right)$ on the nutritional value of butter, lard, and safflor oil was investigated by animal experiments with rats. Impaired growth was noticed when ever heated fats were given. The weight gain was most strongly inhibited by heated safflor oil, while the effect of heated lard and butter was less noticeable. The growth retardation was caused by impaired food consumption and a low absorption of heated fats.

The results of the fatty acid analyses of the nonabsorbed fraction of the ingested fats is discussed.

Acknowledgements. We acknowledge with thanks the assistance of Miss Maija Vahteristo and Miss Ritva Typpö in the practical laboratory work. - This research has been made possible by a grant from the Suomen Kulttuurirahasto and the technical assistance has been partly financed by the National Research Council of Agriculture and Forestry. These contributions are gratefully acknowledged. 


\section{REFERENCES}

(1) Веск, S., \& Peacock, P. R. 1941. Castro-papillomatosis due to vitamin A deficiency induced by heated fats. Brit. Med. J. 2: 81.

(2) Crampton, E. W., Farmer, F. A., \& Berryhill, F. M. 1951. The Effect of heat treatment on the nutritional value of some vegetable oils. J. Nutrition 43: 431 .

(3) Crampton, E. W., Common, R. H., Farmer, F. A., Berryhill, F. M., \& Wiseblatt, L. 1951. Studies to determine the nature of the damage to the nutritive value of some vegetable oils from heat polymerization. Ibid $43: 177$.

(4) Crampton, E. W., Common, R. H., Farmer, F. A., Berryhill, F. M., \& Wiseblatt, L. 1951. Studies to determine the nature of the damage to the nutritive value of some vegetable oils from heat treatment. Ibid 44: 533 .

(5) Нıldiтсн, T. P. 1956. The chemical constitution of natural fats. p. 477. Chapman \& Hall Ltd, London.

(6) Johnson, O. C. \& Kummerow, F. A. 1956. Nutritional evaluation of heated fats. Proc. 8th Res. Conf. Am. Meat Inst. Chigago Ill.

(7) Kritshevsky, D., Tepper, S. A. \& Langan, J. 1962. Influence of short-term heating on composition of edible fats. J. Nutrition 77: 127.

(8) Lane, A., Blickenstoff, D., \& Ivy, A. C. 1950. The carcinogenicity of fat sbrowned by heating. Cancer 3: 1044.

(9) Morris, H. P., Larsen, C. D., \& Lippincotr, S. W. 1943. Effects of feeding heated lard to rats with a histological description of the lesions observed. J. Nat. Cancer Inst. 4: 285.

(10) Raju, N. V., \& Rajagopalan, R. 1955. Nutritive value of heated vegetable oils. Nature $176: 513$.

(11) Roffo, A. H. 1946. Carcinogenic value of oxidated oils. Am. J. Digest. Dis. 13: 33.

(12) Steenbock, H., Irvin, M. H. \& Weber, J. 1936. The comparative rate of absorption of different fats. J. Nutrition 12: 103.

SELOST US :

\section{KUUMENNUKSEN VAIKUTUS RUOANVALMISTUKSESSA ERÄIDEN TAVALLISTEN RASVOJEN RAVINTOARVOON}

ERKKi UKSILA ja RAKel KuRKela

Heìsingin yliopiston ravintokemian laitos

Kasviöljyjen käyttöä ihmisen ravintona on pyritty edistämään maassamme lähinnä voin ja muiden eläinrasvojen kustannuksella. Koska tyydyttämättömät rasvat ovat tunnetusti alttiita kemiallisille muutoksille, on tässä selostetussa tutkimuksessa verrattu kahden tyypillisen suomalaisen ravintorasvan, voin ja laardin, sekä toisaalta runsaasti linolihappoa sisältävän safloriöljyn ravinnollisten ominaisuuksien muuttumista kuumennuksen vaikutuksesta.

Koe-eläiminä käytetyt rotat saivat $60 \%$ dieetin kokonaisenergiasta rasvana, jota oli kuumennettu 20 tuntia $200^{\circ} \mathrm{C}$ :ssa. Vertailuryhmissä oli vastaava määrä tuoretta rasvaa. Kuumentamisen haitallinen vaikutus rasvoihin oli yleisesti todettavissa koe-eläinten kasvun hidastumisena ja erityisesti safloriöljyä annettaessa, kasvun täydellinen pysähtymisenä. Kaikissa kuumennetuilla rasvoilla ruokituissa koeryhmissä laski myös ruoankulutus, dieetin kasvuteho heikkeni ja rasvan imeytyminen ruoansulatuskanavasta aleni. Kaikki nämä muutokset tulivat muita selvempinä esille kuumennetulla safloriöljyllä. Jatkotutkimuksilla pyritään saamaan lisävalaistusta kysymykseen, missä määrin kuumennuksen vaikutus rasvoihin olisi otettava huomioon myös kåytännön ruoanvalmistuksessa. 